\title{
Sistem Informasi Geografis Pasar Tradisional Di Kabupaten Surakarta
}

\author{
Eti Mukharomah \\ Fakultas MIPA, Program Studi D3 Teknik Informatika \\ Universitas Sebelas Maret \\ Email: etimukharomah@student.uns.ac.id
}

\section{Info Artikel}

\section{Kata Kunci :}

Persebaran, Pasar Tradisional, Surakarta.

Keywords :

Distribution, Traditional Markets,

Surakarta.

\section{Tanggal Artikel}

Dikirim : 21 Januari 2019

Direvisi : 21 Februari

Diterima : 12 April 2019

\section{Abstrak}

Pembuatan sistem informasi geografis pasar tradisional di Kabupaten Surakarta menggunakan metode SDLC (Systems Development Life Cycle). Metode SDLC menggunakan pola yang diambil untuk mengembangkan sistem perangkat lunak, yang terdiri dari beberapa tahap antara lain : observasi dan pengumpulan data, pengolahan data, perancangan dan permodelan, desain, implementasi, uji coba dan pemeliharaan. Pembuatan sistem informasi geografis pasar tradisional di Kabupaten Surakarta diharapkan dapat membantu petugas dalam pendataan persebaran pasar tradisional yang ada di Kabupaten Surakarta. Sistem informasi ini dapat menangani manajemen data pasar, jumlah, dan lokasi pasar. Hasil yang telah dicapai dari pembuatan Sistem Informasi Geografis Pasar Tradisional ini adalah menampilkan data pasar, lokasi pasar, klasifikasi pasar serta informasi detail tentang masing-masing pasar. Sistem ini juga mampu menampilkan marker berdasarkan jenis pasar, kelas pasar, wilayah pasar serta barang yang dijual. Sehingga hasil tersebut dapat dijadikan pertimbangan oleh masyarakat dalam mencari informasi pasar dan lokasi pasar secara langsung yang ditampilkan dalam bentuk peta digital. Sistem ini telah dilakukan pengujian menggunakan pengujian black box dan hasilnya sudah sesuai yang diharapkan.

\section{Abstarct}

Red Making geographic information systems for traditional markets in Surakarta Regency using the SDLC (Systems Development Life Cycle) method. SDLC method uses a pattern taken to develop a software system, which consists of several stages including: observation and data collection, data processing, design and modeling, design, implementation, trial and maintenance. The making of a geographic information system for traditional markets in Surakarta Regency is expected to be able to assist officers in the data collection of traditional markets in Surakarta Regency. This information system can handle market data management, number, and market location. The results that have been achieved from making the Traditional Market Geographical Information System are displaying market data, market location, market classification and detailed information about each market. This system is also able to display markers based on market type, market class, market area and goods sold. So that these results can be used as a consideration by the community in finding market information and market location directly which is displayed in the form of digital maps. This system has been tested using black box testing and the results are as expected. 


\section{PENDAHULUAN}

Pasar merupakan tempat bertemunya antara penjual dan pembeli yang juga ditandai dengan adanya proses transaksi atau tawar menawar barang yang diperjual belikan. Keberadaan pasar di suatu wilayah mampu meningkatkan perekonomian dan pendapatan daerah. Di kota Surakarta terdapat banyak pasar tradisional yang tersebar dibeberapa kecamatan yang ada di wilayah Surakarta. Saat ini informasi mengenai lokasi pasar tradisional yang dikelola Dinas Pengelolaan Pasar kota Surakarta masih sangat sedikit dan belum banyak informasi mengenai pasar yang disajikan ke dalam bentuk peta digital sehingga masyarakat kesulitan untuk menemukan lokasi dan informasi pasar.

Tujuan dari pembuatan Sistem Informasi Geografis Pasar Tradisional di Kabupaten Surakarta adalah dapat menampilkan marker berdasarkan klasifikasi pasar, wilayah pasar serta barang yang dijual untuk dijadikan pertimbangan oleh masyarakat dalam mencari informasi pasar dan lokasi pasar secara langsung yang ditampilkan dalam bentuk peta digital.

Hasil yang telah dicapai dari pembuatan Sistem Informasi Geografis Pasar Tradisional ini adalah menampilkan data pasar, lokasi pasar, klasifikasi pasar serta informasi detail tentang masing-masing pasar. Sistem ini juga mampu menampilkan marker berdasarkan jenis pasar, kelas pasar, wilayah pasar serta barang yang dijual. Sehingga hasil tersebut dapat dijadikan pertimbangan oleh masyarakat dalam mencari informasi pasar dan lokasi pasar secara langsung yang ditampilkan dalam bentuk peta digital. Sistem ini telah dilakukan pengujian menggunakan pengujian black box dan hasilnya sudah sesuai yang diharapkan.

Menurut Penelitian [1] yang berjudul "Rancang Bangun Sistem Informasi Geografis Sebaran Tempat Riset Teknologi Informasi Di Kota Garut" yang mengembangkan sistem menggunakan teknologi Geographic Information System (GIS) untuk melihat informasi sebaran tempat serta informasi aktifitas penelitian yang dilakukan mahasiswanya. Kemudian mengetahui informasi kajian penelitian apa saja yang ada di daerah tersebut. Hal ini diperlukan mahasiswa dan jurusan untuk menentukan apakah penelitian tersebut telah dilakukan atau belum, serta sebagai acuan apakah penelitian tersebut layak disetujui oleh pihak jurusan atau tidak. Dalam membangun teknologi GIS digunakan suatu metoda pengumpulan data dan metoda penelitian berbasis objek, serta dilakukan pengujian dengan blackbox testing. Akhir dari produk ini berupa aplikasi GIS sebaran tempat RISTI yang telah memenuhi kebutuhan fungsional jurusan Teknik Informatika terhadap sistem RISTI yang dibangun.

Menurut penelitian yang dilakukan oleh [2] yang berjudul "Implementasi Sistem Informasi Geografis Menggunakan Google Maps Api dalam Pemetaan Asal Mahasiswa" yang mengembangkan Sistem Informasi Geografis dengan memanfaatkan Google Maps ini menunjukkan bahwa eksistensi dari keberadaan Fakultas Teknik Universitas Muhammadiyah Ponorogo masih sebatas di Karisidenan Madiun Jawa Timur. Dengan sistem informasi geografis (SIG) dapat diketahui secara geografis tentang asal-muasal mahasiswa yang mengikuti perkuliahan di Fakultas Teknik. Dari sistem bisa menghasilkan sebuah output tentang gambaran darimana asal mahasiswa sehingga pihak kampus bisa mengetahui seberapa dikenalnya kampus di masyarakat.

Menurut penelitian yang telah dilakukan oleh [3] berjudul "Sistem Informasi Geografis Pemetaan Potensi SMA/SMK Berbasis Web (Studi Kasus : Kabupaten Kebumen)" yang mengembangkan sistem informasi geografis menggunakan metode pengumpulan data dengan cara observasi, studi literatur, dan wawancara. Setelah data dikumpul dilakukan analisis kebutuhan sistem dan perancangan sistem yang meliputi perancangan proses, perancangan database, perancangan struktur menu dan perancangan interface. Selanjutnya implementasi sistem dengan memanfaatkan Google Map Service dan bahasa pemrograman PHP bebasis Framework Codeigniter. Setelah aplikasi dihasilkan maka dilakukan uji program dengan Black Box Test dan Alpha Test. Keluaran dari penelitian ini adalah sebuah aplikasi Sistem Informasi Geografis Pemetaan Potensi SMA/SMK Berbasis Web di kabupaten Kebumen yang dapat memberikan informasi tentang SMA/SMK. Hasil pengujian sistem menunjukan bahwa sistem informasi ini layak dan dapat dipergunakan.

Menurut penelitian yang telah dilakukan oleh [4] yang berjudul "Sistem Informasi Geografis Pencarian Rute Optimum Obyek Wisata Kota Yogyakarta Dengan Algoritma Floyd-Warshall" mengembangkan Sistem Informasi Geografis tentang pencarian rute optimum pencarian lokasi objek wisata tertentu. Metode pencarian rute optimum yang digunakan adalah algoritma FloydWarshall, metode ini di ambil karena sangat efektif digunakan dalam menangani masalah rute optimum. Pembatasan masalah pada penelitian ini antara lain penggunaan Sistem Informasi Geografis yang bersifat desktop dan pencarian lokasi wisata tidak bersifat real time, yang secara langsung mengetahui keberadaan user. Akan tetapi user harus menginputkan lokasi awal (keberadaan) dan lokasi akhir (tujuannya). Rute optimum yang dimaksud adalah rute/jalan tercepat yang akan dilalui dengan kendaraan roda empat.

Dari tinjauan pustaka yang telah di paparkan di atas dapat disimpulkan bahwa dari penelitian yang dilakukan oleh peneliti adalah adanya perbedaan studi kasus dimana dalam penelitian ini mengambil studi kasus di wilayah 
Surakarta. Kemudian output dari produk yang di buat yaitu berupa sebuah sistem yang dapat menampilkan lokasi dan informasi pasar tradisional serta persebaran pasar yang ada di wilayah Kabupaten Surakarta.

\section{METODE PENELITIAN}

Metode penelitian yang digunakan dalam pembuatan Sistem Informasi Geografis Pasar Tradisional di Kabupaten Surakarta ini siklus SDLC (Systems Development Life Cycle) yaitu metode waterfall yang mempunyai beberapa tahap diantaranya sebagai berikut :

\subsection{Observasi Dan Pengumpulan Data}

Tahap pertama kali saat pembuatan sebuah sistem adalah melakukan observasi dan pengumpulan data. Pengumpulan data dimaksudkan untuk mengumpulkan seluruh data dan informasi yang berkaitan dengan studi kasus yang akan dibuat. Pengumpulan data dilakukan dengan meminta data pasar ke Dinas Perdagangan wilayah Surakarta bagian bidang pasar.

\subsection{Perancangan Sistem}

Tahap kedua dari pembuatan sistem geografis pasar ini adalah perencanaan sistem. Setelah memperoleh data, maka akan diperoleh kebutuhan dari keseluruhan sistem yang akan diaplikasikan dalam bentuk website.

\subsection{Desain}

Desain sistem adalah tahap setelah analisis sistem dari siklus pengembangan sistem yang mendefinisikan dari kebutuhan-kebutuhan fungsional, persiapan untuk rancang bangun implementasi, menggambarkan bagaimana suatu sistem dibentuk yang dapat berupa penggambaran, perencanaan dan pembuatan sketsa atau pengaturan dari beberapa elemen yang terpisah ke dalam satu kesatuan yang utuh dan berfungsi, termasuk menyangkut konfigurasi dari komponen-komponen perangkat lunak dan perangkat keras dari suatu sistem.

Desain Database adalah proses menghasilkan detail model data dari basis data (database). Desain Interface adalah rancangan tampilan antarmuka dari website, rancangan antarmuka ini dibuat semenarik mungkin tetapi tidak melupakan unsur kemudahan user ketika mengunjungi website. Desain user interface digunakan untuk dasar membuat tampilan aplikasi yang nantinya akan dipakai oleh user.

\subsection{Implementasi}

Tahap berikutnya adalah implementasi yaitu mengimplementasikan rancangan dari tahap-tahap sebelumnya. Pembuatan database sesuai skema rancangan. Pembuatan aplikasi berdasarkan desain sistem. Tahapan implementasi adalah inti dari seluruh tahapan pembuatan aplikasi, pada tahapan inilah sebuah aplikasi benar-benar dibuat dari awal berpedoman pada rancangan-rancangan yang telah dibuat sebelumnya.

\subsection{Pengujian Perangkat Lunak}

Sebuah website yang telah dibuat harus melalui proses pengujian untuk menghindari terjadinya kesalahan dalam sistem. Setiap link harus melalui proses pengujian.

\subsection{Pemeliharaan}

Dilakukan oleh admin yang ditunjuk untuk menjaga sistem tetap mampu beroperasi secara benar melalui kemampuan sistem dalam mengadaptasikan diri sesuai dengan kebutuhan. Pemeliharaan akan dilakukan secara rutin dan berkala agar fungsionalitas sistem tetap berjalan dengan baik. 


\section{HASIL DAN PEMBAHASAN}

\subsection{Proses Bisnis Sistem}

Proses bisnis dari Sistem Informasi Geografis Pasar Tradisional di Surakarta adalah Super Admin dapat menambahkan, mengubah, dan menghapus data admin serta data pasar. Admin juga dapat melakukan manajemen data pasar. Proses bisnis Sistem Informasi Geografis Pasar Tradisional di Surakarta dapat dilihat pada Gambar 1.

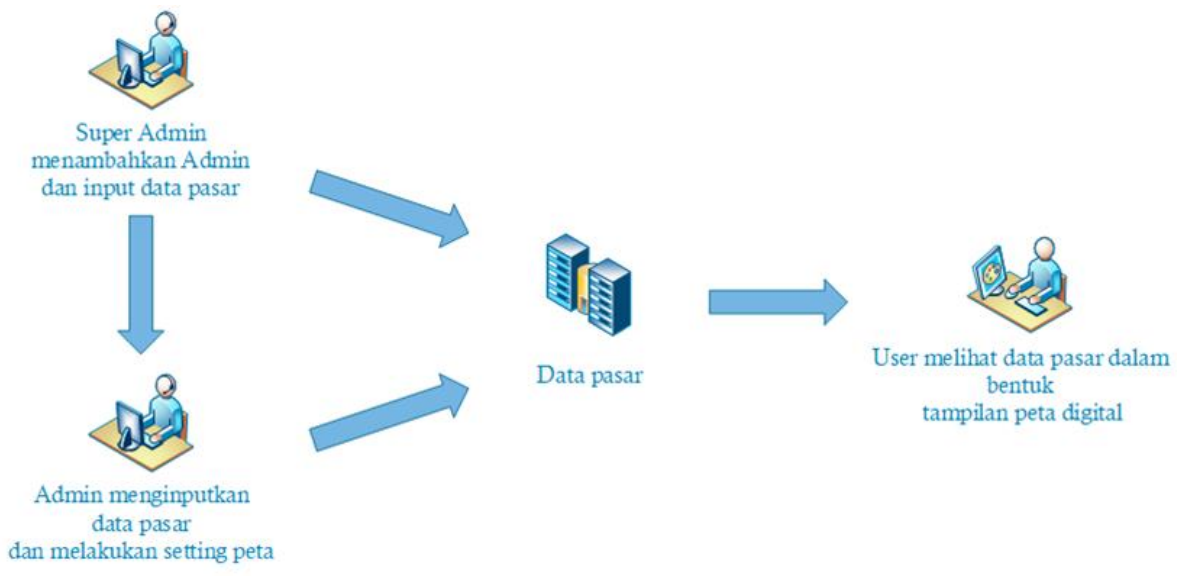

\section{Gambar 1. Proses Bisnis Sistem}

\subsection{Software Requirement Specification(SRS)}

Spesifikasi untuk pembuatan Sistem Informasi Geografis Pasar Tradisional di Wilayah Surakarta terdiri dari kebutuhan fungsional dan kebutuhan non fungsional yang dijelaskan sebagai berikut :

\subsubsection{Kebutuhan Fungsional}

Kebutuhan fungsional merupakan kebutuhan yang diperlukan pada sistem yang biasanya berhubungan dengan proses bisnis dapat dilihat pada Tabel 1.

Tabel 1. Tabel Kebutuhan Fungsional

\begin{tabular}{lll}
\hline \multicolumn{1}{c}{ Kode } & \multicolumn{1}{c}{ Deskripsi } & \multicolumn{1}{c}{ Aktor } \\
\hline FR01 & Managemen data admin & Super Admin \\
\hline FR02 & Managemen data pasar & Super Admin, Admin \\
\hline FR03 & Managemen data jenis pasar & Super Admin, Admin \\
\hline FR04 & Managemen data kelas pasar & Super Admin, Admin \\
\hline FR05 & Managemen data kelurahan & Super Admin, Admin \\
\hline FR06 & Managemen data kecamatan & Super Admin, Admin \\
\hline FR07 & Managemen data barang & Super Admin, Admin \\
\hline FR08 & Managemen data kategori barang & Super Admin, Admin \\
\hline FR09 & Managemen data sub kategori barang & Super Admin, Admin \\
\hline FR010 & Sistem mampu mencari data pasar berdasarkan barang & Super Admin, Admin, \\
& yang dijual, wilayah, dan klasifikasi pasar & User \\
\hline FR011 & Sistem mampu menampilkan detail pasar & Super Admin, Admin, \\
& & User \\
\hline
\end{tabular}

\subsubsection{Kebutuhan Non Fungsional}

Kebutuhan non fungsional merupakan kebutuhan-kebutuhan yang berhubungan dengan interaksi antar user dengan aplikasi yang dibuat dapat dilihat pada Tabel 2. 
Tabel 2. Tabel Kebutuhan Non Fungsional

\begin{tabular}{lll}
\hline No & Kode & Deskripsi \\
\hline 1 & NFR01 & Super Admin dan Admin menggunakan login untuk masuk ke sistem \\
\hline 2 & NFR02 & Koneksi internet untuk menampilkan marker pada maps \\
\hline
\end{tabular}

\subsection{Perancangan Basis Data}

\subsubsection{RAT (Relasi Antar Tabel)}

Relasi antar tabel pada Sistem Informasi Geografis Pasar Tradisional di Wilayah Surakarta dapat dilihat pada Gambar 2.

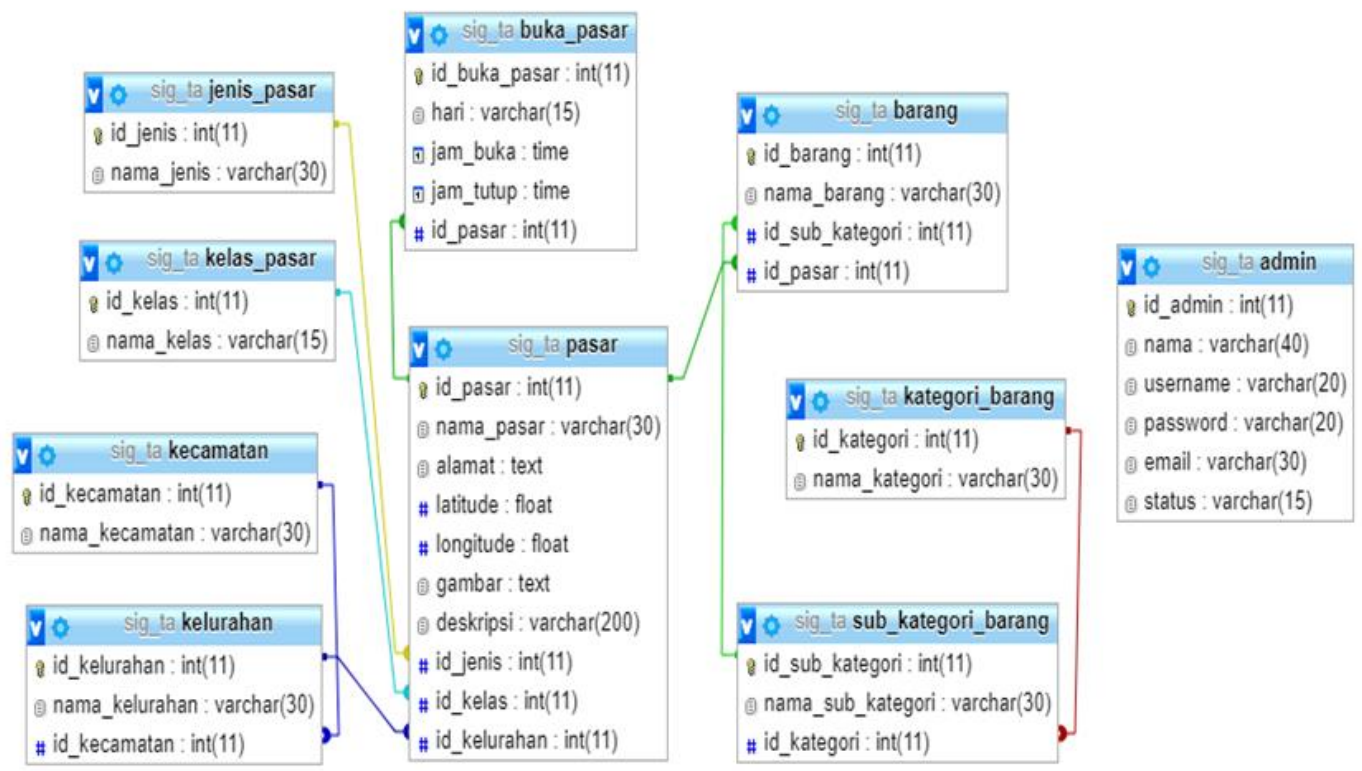

\section{Gambar 2. Gambar Relasi Antar Tabel}

3.3.2 ERD (Entity Relationship Diagram)

Entity Relationship Diagram pada Sistem Informasi Geografis Pasar Tradisional di Wilayah Surakarta memiliki enam entitas dapat dilihat pada Gambar 3. 


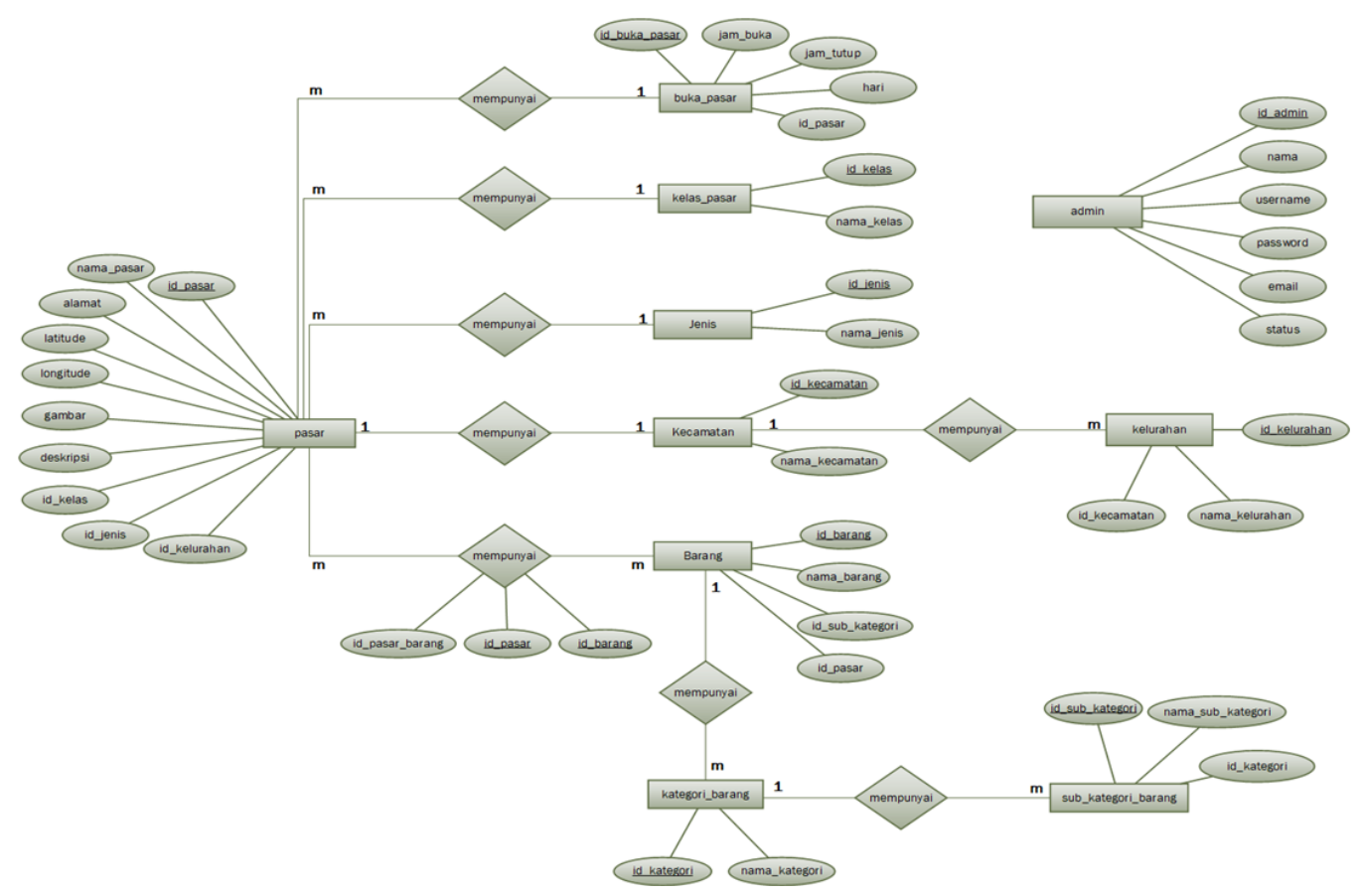

Gambar 3. Gambar Entity Relationship Diagram

\subsection{Tampilan Sistem}

Halaman tampilan home merupakan halaman yang digunakan untuk menampilkan marker pasar. Berikut tampilan home dapat di lihat pada Gambar 4.

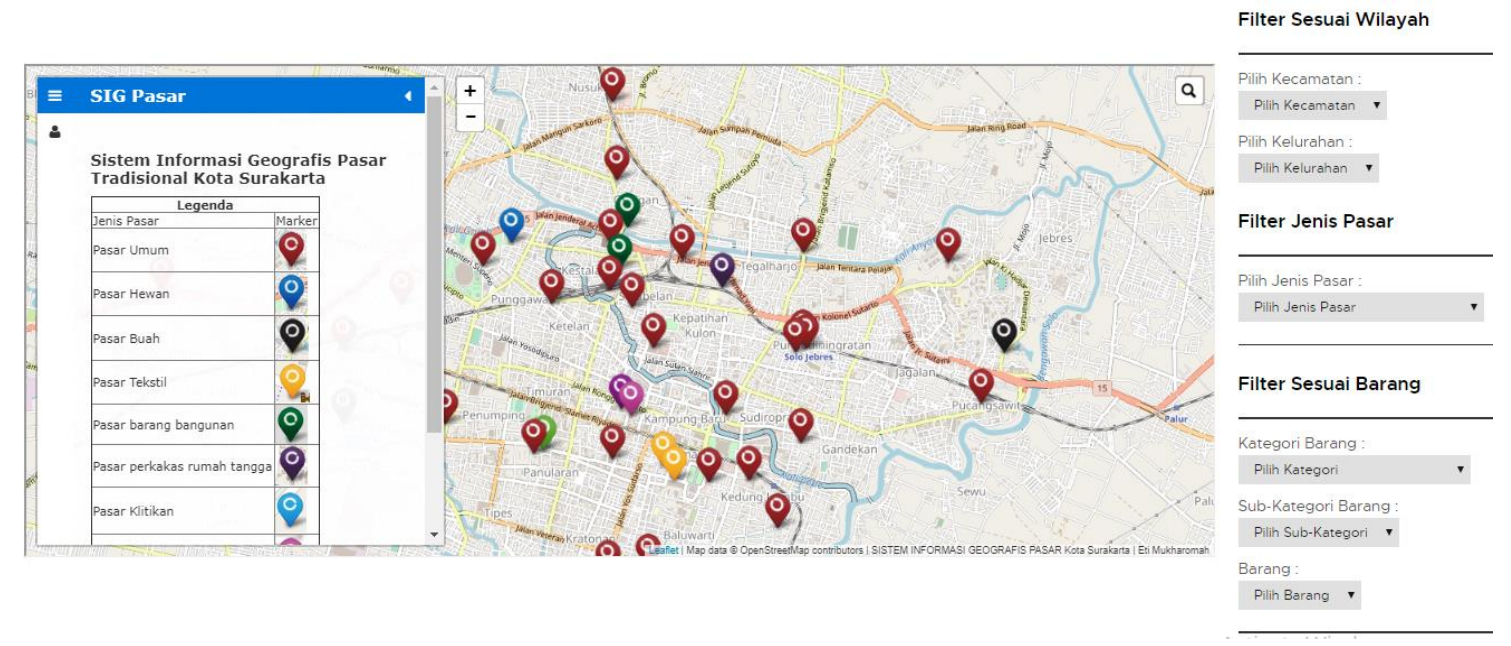

Gambar 4. Tampilan Home

Berikut tampilan filter pasar berdasarkan wilayah, klasifikasi pasar dan barang apa saja yang dijual dapat diliihat pada Gambar 5. 


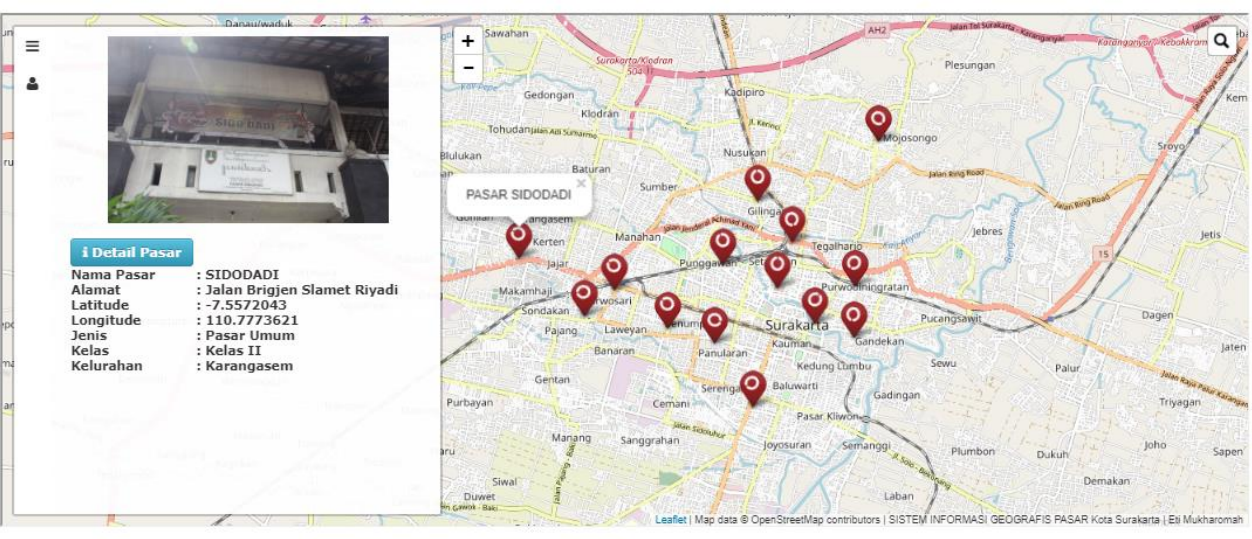

Filter Sesuai Wilayah

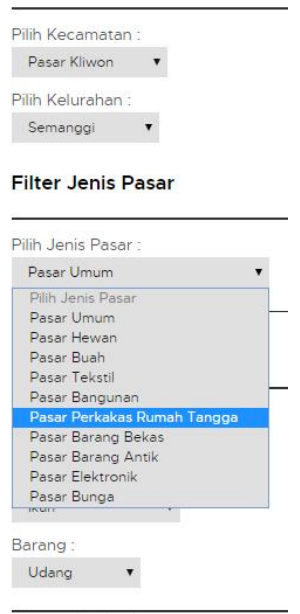

Gambar 5. Tampilan Filter Pasar

Berikut tampilan detail pasar terdapat deskripsi pasar informasi lainnya dapat dilihat pada Gambar 6.

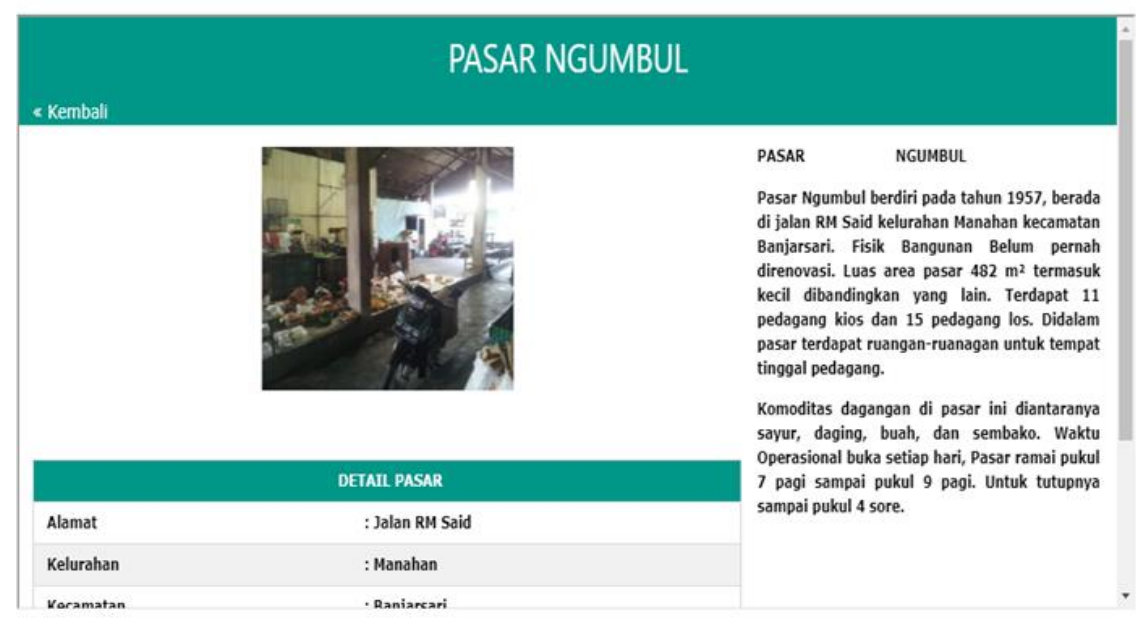

Filter Sesuai Wilayah

Pilin Kecamotan

Pilh Kecamatan -

Pilih Kelurahon

Pilin Keiurahan ,

Filter Sesuai Barang

Kategori Barang

Pinh Karegon .

Sub-Kategori Barang

Pin Sub-Kategori -

Barang

Plin Barang

\section{Gambar 6. Tampilan Detail Pasar}

\subsection{Pengujian Sistem}

Pengujian Sistem Informasi Geografis Pasar Tradisional di Kabupaten Surakarta menggunakan blackbox testing dapat dilihat pada Tabel 3.

Tabel 3. Tabel Pengujian

\begin{tabular}{|c|c|c|c|c|}
\hline No. & Kasus/ Form yang diuji & Skenario Sistem & $\begin{array}{ll}\text { Hasil } & \text { yang } \\
\text { Diharapkan } & \end{array}$ & $\begin{array}{l}\text { Hasil } \\
\text { Pengujian }\end{array}$ \\
\hline 1 & Login user & $\begin{array}{lr}\text { User } & \text { login } \\
\text { menggunakan } & \\
\text { username } & \text { dan } \\
\text { password yang } & \text { sudah } \\
\text { ditentukan } & \end{array}$ & $\begin{array}{l}\text { User dapat login ke } \\
\text { halaman admin }\end{array}$ & Berhasil \\
\hline 2 & Managemen data admin & $\begin{array}{l}\text { Super Admin memilih } \\
\text { menu admin untuk }\end{array}$ & $\begin{array}{l}\text { Super Admin dapat } \\
\text { menampilkan, }\end{array}$ & Berhasil \\
\hline
\end{tabular}




\begin{tabular}{|c|c|c|c|c|}
\hline & & $\begin{array}{l}\text { menampilkan, } \\
\text { menambahkan, } \\
\text { memperbaharui dan } \\
\text { menghapus semua } \\
\text { data admin }\end{array}$ & $\begin{array}{l}\text { menambahkan, } \\
\text { memperbaharui, dan } \\
\text { menghapus data } \\
\text { admin }\end{array}$ & \\
\hline 3 & Managemen data pasar & $\begin{array}{lr}\text { Super Admin } & \text { dan } \\
\text { Admin memilih } & \text { menu } \\
\text { pasar } & \text { untuk } \\
\text { menampilkan, } & \\
\text { menambahkan, } & \\
\text { memperbaharui } & \text { dan } \\
\text { menghapus } & \text { semua } \\
\text { data pasar } & \\
\end{array}$ & $\begin{array}{l}\text { Super Admin dan } \\
\text { Admin dapat } \\
\text { menampilkan, } \\
\text { menambahkan, } \\
\text { memperbaharui, dan } \\
\text { menghapus data } \\
\text { pasar }\end{array}$ & Berhasil \\
\hline 4 & $\begin{array}{l}\text { Managemen data jenis } \\
\text { pasar }\end{array}$ & $\begin{array}{lr}\text { Super Admin } & \text { dan } \\
\text { Admin memilih } & \text { menu } \\
\text { pasar } & \text { untuk } \\
\text { menampilkan, } & \\
\text { menambahkan, } & \\
\text { memperbaharui } & \text { dan } \\
\text { menghapus } & \text { semua } \\
\text { data jenis pasar } & \\
\end{array}$ & $\begin{array}{l}\text { Super Admin dan } \\
\text { Admin dapat } \\
\text { menampilkan, } \\
\text { menambahkan, } \\
\text { memperbaharui, dan } \\
\text { menghapus data jenis } \\
\text { pasar }\end{array}$ & Berhasil \\
\hline 5 & $\begin{array}{l}\text { Managemen data kelas } \\
\text { pasar }\end{array}$ & $\begin{array}{lr}\text { Super Admin } & \text { dan } \\
\text { Admin memilih menu } \\
\text { pasar } & \text { untuk } \\
\text { menampilkan, } & \\
\text { menambahkan, } & \\
\text { memperbaharui dan } \\
\text { menghapus semua } \\
\text { data kelas pasar }\end{array}$ & $\begin{array}{l}\text { Super Admin dan } \\
\text { Admin dapat } \\
\text { menampilkan, } \\
\text { menambahkan, } \\
\text { memperbaharui, dan } \\
\text { menghapus data } \\
\text { kelas pasar }\end{array}$ & Berhasil \\
\hline 6 & Managemen data kelurahan & $\begin{array}{lr}\text { Super Admin } & \text { dan } \\
\text { Admin memilih } & \text { menu } \\
\text { pasar } & \text { untuk } \\
\text { menampilkan, } & \\
\text { menambahkan, } & \\
\text { memperbaharui } & \text { dan } \\
\text { menghapus } & \text { semua } \\
\text { data kelurahan } & \\
\end{array}$ & $\begin{array}{l}\text { Super Admin dan } \\
\text { Admin dapat } \\
\text { menampilkan, } \\
\text { menambahkan, } \\
\text { memperbaharui, dan } \\
\text { menghapus data } \\
\text { kelurahan }\end{array}$ & Berhasil \\
\hline 7 & $\begin{array}{l}\text { Managemen } \\
\text { kecamatan }\end{array}$ & $\begin{array}{lrr}\text { Super Admin } & \text { dan } \\
\text { Admin memilih } & \text { menu } \\
\text { pasar } & \text { untuk } \\
\text { menampilkan, } & \\
\text { menambahkan, } & \\
\text { memperbaharui } & \text { dan } \\
\text { menghapus } & \text { semua } \\
\text { data kecamatan } & \\
\end{array}$ & $\begin{array}{l}\text { Super Admin dan } \\
\text { Admin dapat } \\
\text { menampilkan, } \\
\text { menambahkan, } \\
\text { memperbaharui, dan } \\
\text { menghapus data } \\
\text { kecamatan }\end{array}$ & Berhasil \\
\hline 8 & Managemen data barang & $\begin{array}{lr}\text { Super Admin } & \text { dan } \\
\text { Admin memilih } & \text { menu } \\
\text { pasar } & \text { untuk } \\
\text { menampilkan, } & \\
\text { menambahkan, } & \\
\text { memperbaharui } & \text { dan } \\
\text { menghapus r semua } \\
\text { data barang }\end{array}$ & $\begin{array}{l}\text { Super Admin dan } \\
\text { Admin dapat } \\
\text { menampilkan, } \\
\text { menambahkan, } \\
\text { memperbaharui, dan } \\
\text { menghapus data } \\
\text { barang }\end{array}$ & Berhasil \\
\hline 9 & $\begin{array}{l}\text { Managemen data kategori } \\
\text { barang }\end{array}$ & $\begin{array}{lrr}\text { Super } & \text { Admin } & \text { dan } \\
\text { Admin } & \text { memilih } & \text { menu }\end{array}$ & $\begin{array}{lrr}\text { Super } & \text { Admin } \begin{array}{r}\text { dan } \\
\text { Admin }\end{array} & \text { dapat }\end{array}$ & Berhasil \\
\hline
\end{tabular}




\begin{tabular}{|c|c|c|c|c|}
\hline & & $\begin{array}{l}\text { pasar untuk } \\
\text { menampilkan, } \\
\text { menambahkan, } \\
\text { memperbaharui dan } \\
\text { menghapus semua } \\
\text { data kategori barang }\end{array}$ & $\begin{array}{l}\text { menampilkan, } \\
\text { menambahkan, } \\
\text { memperbaharui, dan } \\
\text { menghapus data } \\
\text { kategori barang }\end{array}$ & \\
\hline 10 & $\begin{array}{l}\text { Managemen data sub } \\
\text { kategori barang }\end{array}$ & $\begin{array}{lr}\text { Super Admin dan } \\
\text { Admin memilih menu } \\
\text { pasar } & \text { untuk } \\
\text { menampilkan, } \\
\text { menambahkan, } \\
\text { memperbaharui dan } \\
\text { menghapus semua } \\
\text { data sub kategori } \\
\text { barang }\end{array}$ & $\begin{array}{l}\text { Super Admin dan } \\
\text { Admin dapat } \\
\text { menampilkan, } \\
\text { menambahkan, } \\
\text { memperbaharui, dan } \\
\text { menghapus data sub } \\
\text { kategori barang }\end{array}$ & Berhasil \\
\hline 11 & $\begin{array}{l}\text { Menampilkan marker } \\
\text { berdasarkan wilayah }\end{array}$ & $\begin{array}{lr}\text { Pengguna } & \text { memilih } \\
\text { dropdown kecamatan } \\
\text { dan kelurahan }\end{array}$ & $\begin{array}{lrr}\text { Marker } & \text { pasar } & \text { akan } \\
\text { muncul } & \text { pada } & \text { map } \\
\text { sesuai } & \text { dengan } \\
\text { wilayah } & & \\
\end{array}$ & Berhasil \\
\hline 12 & $\begin{array}{l}\text { Menampilkan marker } \\
\text { berdasarkan jenis pasar }\end{array}$ & $\begin{array}{lr}\text { Pengguna } & \text { memilih } \\
\text { dropdown } & \text { filter } \\
\text { berdasarkan jenis pasar }\end{array}$ & $\begin{array}{lll}\text { Marker pasar } & \text { akan } \\
\text { muncul pada } & \text { map } \\
\text { sesuai dengan jenis } \\
\text { pasar }\end{array}$ & Berhasil \\
\hline 13 & $\begin{array}{l}\text { Menampilkan marker } \\
\text { berdasarkan kelas pasar }\end{array}$ & $\begin{array}{lr}\text { Pengguna } & \text { memilih } \\
\text { dropdown } & \text { filter } \\
\text { berdasarkan } & \text { kelas } \\
\text { pasar } & \\
\end{array}$ & $\begin{array}{l}\text { Marker pasar akan } \\
\text { muncul pada map } \\
\text { sesuai dengan kelas } \\
\text { pasar }\end{array}$ & Berhasil \\
\hline 14 & $\begin{array}{l}\text { Menampilkan marker } \\
\text { berdasarkan barang yang di } \\
\text { jual di pasar }\end{array}$ & $\begin{array}{lr}\text { Pengguna } & \text { memilih } \\
\text { dropdown } & \text { filter } \\
\text { berdasarkan } & \text { kategori } \\
\text { barang, sub } & \text { kategori } \\
\text { barang dan barang }\end{array}$ & $\begin{array}{l}\text { Marker pasar akan } \\
\text { muncul pada map } \\
\text { sesuai dengan barang } \\
\text { yang dijual di pasar }\end{array}$ & Berhasil \\
\hline
\end{tabular}

\section{KESIMPULAN}

Penelitian sistem informasi geografis telah dilakukan menghasilkan kesimpulan bahwa dalam pembuatan Sistem Informasi Geografis Pasar Tradisional di Kabupaten dibangun sebuah sistem informasi geografis yang mampu menampilkan marker berdasarkan klasifikasi pasar, wilayah pasar serta barang yang dijual untuk dijadikan pertimbangan oleh masyarakat dalam mencari informasi pasar dan lokasi pasar secara langsung yang ditampilkan dalam bentuk peta digital. .

Sistem yang dibangun memberikan hasil dengan menampilkan data pasar, lokasi pasar, klasifikasi pasar serta informasi detail tentang masing-masing pasar. Sistem ini juga mampu menampilkan marker berdasarkan jenis pasar, kelas pasar dan wilayah pasar serta barang yang dijual.

\section{DAFTAR PUSTAKA}

[1] Bustomi, Y., Ramdhani, M. A., \& Cahyana, R. (2012). Rancang Bangun Sistem Informasi Geografis Sebaran Tempat Riset Teknologi Informasi Di Kota Garut. Jurnal STT Garut, 1-2 Volume 09.

[2] Masykur, F. (2014 ). Implementasi Sistem Informasi Geografis Menggunakan Google Maps Api dalam Pemetaan Asal Mahasiswa. Jurnal SIMETRIS, 186 Vol 5.

[3] Kharistiani, E., \& Aribowo, E. (2013). SISTEM INFORMASI GEOGRAFIS PEMETAAN POTENSI SMA/SMK BERBASIS WEB (Studi Kasus : Kabupaten Kebumen). Jurnal Sarjana Teknik Informatika, 48 Vol 1.

[4] Saputra, R. (2011). Sistem Informasi Geografis Pencarian Rute Optimum Obyek Wisata Kota Yogyakarta Dengan Algoritma Floyd-Warshall. Jurnal Matematika, 19-24 Vol 14. 